\title{
A convicção contextualizada e a verdade negociada no processo penal: desmistificando a confissão como elemento de convencimento pleno do julgador penal
}

The contextualized conviction and the negotiated truth in the
criminal process: demystifying confession as an element
of full conviction of the criminal judge

Paulo Gustavo Rodrigues ${ }^{1}$

Mestrando em Direito na UFAL (Maceió/AL)

paulo.lima.rodrigues@tjpe.jus.br

http://lattes.cnpq.br/4136000039136925

http://orcid.org/0000-0001-6670-6557

Resumo: O presente artigo busca analisar a problemática da verdade no Processo Penal, especialmente no contexto da análise dos elementos de convencimento do julgador e da valoração da confissão do acusado. A partir de uma revisão bibliográfica, buscar-se-á trabaIhar o status da busca da verdade no processo penal para desmistificar o alto valor probatório que sempre se conferiu à confissão penal, especialmente se baseando na rejeição à negociabilidade acerca da verdade de premissas fáticas. Ademais, analisar-se-á de que forma as delações premiadas configuram uma desvirtuação das funções do processo penal no sentido de se convencionar um standard de aceitabilidade fática que ignore a busca da verdade como fundamento ético da persecução penal.

Palavras-chave: verdade; confissão; convencimento judicial; justiça criminal negocial.

1 Mestrando em Direito Público na Universidade Federal de Alagoas. Especialista em Ciências Criminais (UNIDERP/IPAN). Assessor de Magistrado no Tribunal de Justiça de Pernambuco (TJPE). 
ABSTRACT: This article intends to analyze the problem of the truth in criminal procedure, especially in the context of the elements of judicial convincing. From a bibliographic review, we intend to discuss the status of the search for the truth in criminal procedure, as a mean to demystify the high probative value that was always assigned to criminal confessions, especially based on the rejection of negotiability of factual premises. Furthermore, we will analyze in which way awarded incrimination pervert the functions of criminal procedure as it stands as an agreement of a standard of factual acceptability that ignores the search of the truth as an ethical fundament of the criminal persecution.

KeY-woRds: truth; confession; judicial conviction; negotiated criminal justice.

SUMÁRIo: Introdução; 1 . A busca da verdade no processo penal; 2. A insuficiência da confissão para formação da certeza condenatória: a busca por uma convicção contextualizada; 3. A fundamentação da decisão penal e os equívocos da súmula $\mathrm{n}$. 545, do Superior Tribunal de Justiça; 4. A colaboração premiada e negociabilidade da verdade no processo penal; Conclusão; Referências.

\section{INTRODUÇÃO}

A confissão sempre foi tida como a prova suprema ${ }^{2}$, especialmente no Processo Penal. Como um vestígio de uma cultura policialesca influenciada pelo cinema americano, busca-se a todo custo, na atividade policial e judicial, a obtenção da confissão, por vezes recorrendo a mecanismos ilícitos de constrangimento físico ou psicológico, como se esse meio de prova possuísse o condão de solucionar definitivamente o caso em análise.

2 Embora alguns manuais, influenciados pela metodologia do próprio Código de Processo Penal, indiquem a confissão como meio de prova, vê-se que a doutrina mais moderna tem trabalhado ela como elemento de prova, um resultado eventual do interrogatório, este sim um legítimo meio de prova, como se lê em: BADARÓ, Gustavo. Processo Penal. $3^{\mathrm{a}}$ Ed., rev., atual. e ampl.. São Paulo: Editora Revista dos Tribunais, 2015, p. 447. 
A proposta deste estudo, naturalmente limitado e sem pretensão de exaustão do tema, é analisar as problemáticas atreladas a esta compreensão da confissão como mecanismo único e pleno de convencimento do julgador penal, dentro do contexto da busca da verdade como fundamento ético do processo penal.

Buscando construir a ideia de uma convicção contextualizada em contraponto à verdade negociada da confissão, analisaremos de que forma se poderia compreender, no Processo Penal, a construção de uma certeza jurídica apta a desconstituir a presunção de inocência, especialmente em face do regramento legal das colaborações premiadas, que vieram reavivar a força probatória da confissão.

\section{A BUSCA DA VERDADE NO PROCESSO PENAL}

Muito se construiu na doutrina processual penal acerca do conceito de verdade, notadamente da clássica divisão entre verdade real e verdade processual e das consequências da incessante busca judicial pela primeira.

Sem a pretensão de profundos estudos epistemológicos, entendemos a verdade real como aquela do mundo fático, correspondente ao que efetivamente ocorreu na natureza, e cuja alcançabilidade humana é, em essência, impossível. Para os céticos pirronianos, assim chamados os discípulos do filósofo grego Pirro de Elis, a verdade se encontra em um abismo, e seria inalcançável aos homens por saltos gnosiológicos que a realidade passa até chegar à sua descrição ${ }^{3}$.

Um desses saltos seria decorrente das diferentes percepções da realidade pelos homens, geradas por divergências na constituição física, psicológica, cultural ou social das pessoas. Alguém pode descrever outra pessoa como bela, e esta ser a perfeita correspondência da sua concepção própria de beleza, e outra pessoa descrever o mesmo ser como feio, e nenhuma das duas pessoas estaria mentindo. Ademais, alguém pode descrever um som como alto e outra pessoa o descrever como bai-

3 LAÊRTIOS, Diôgenes. Vidas e doutrinas dos filósofos ilustres. Tradução do grego, introdução e notas: Mário da Gama. $2^{a}$ Ed. Brasília: Editora da Universidade de Brasília, 2008, p. 272-273. 
xo em face de divergências nas formações físicas de seu canal auditivo, e, novamente, como dizer qual a realidade?

Ademais, concluem os pirronianos que até circunstâncias da natureza podem mudar a percepção da pessoa a respeito de determinada realidade fática: as cores se alteram a depender da luminosidade do ambiente, o peso relativo de um objeto se suaviza se ele estiver dentro da água, etc.

Não negam a existência da verdade, como também não o negamos, mas apenas que ela por essência é inalcançável à natureza humana. Os céticos pirronianos admitem que podemos perceber a realidade, mas dizem somente que não sabemos o que percebemos, dando exemplo quando afirmam que "percebemos que o fogo queima, porém suspendemos o juízo quando se trata de saber se queimar é da natureza do fogo"*

Transpondo o raciocínio ao processo judicial, vê-se que ele é um instrumento ainda menos apto a se alcançar a verdade. Nele, observam-se diversos outros saltos da mesma natureza, decorrentes das limitações de expressão e vocabulário das pessoas para transmitirem em palavras as suas já falhas e diversas compreensões, e das idiossincrasias dos julgadores que precisam absorver estas falhas transmissões de falhas compreensões e novamente transformá-las em palavras escritas.

Tal inalcançabilidade levou alguns a negar a própria existência de uma única verdade, enquanto outros, não rejeitando sua existência ontológica, buscaram construir para fins jurídicos uma noção de verdade processual, uma narrativa fática que busca se aproximar da real, mas que se constrói pela conformação do julgador com aquilo que foi provado ou confirmado nos autos, em uma ideia de probabilidade ou plausibilidade. Luigi Ferrajoli lembra, abordando um conceito de verdade processual, que a afirmação no processo de que algo é "verdade" ou "verdadeiro" é, precisamente, a afirmação de que "estas são (plausivelmente) verdadeiras pelo que sabemos sobre elas, ou seja, em relação ao conjunto dos conhecimentos confirmados que dela possuímos”.

4 LAERTIO, Diôneges. Op. Cit., p. 278.

5 FERRAJOLI, Luigi. Direito e razão: teoria do garantismo penal. $3^{\mathrm{a}} \mathrm{Ed}$. rev. São Paulo: Editora Revista dos Tribunais, 2010, p. 53. 
A verdade que nos interessa, então, se desvincula da ideia utópica de correspondência plena com a realidade e assume a feição relativista de conformação ou aceitação de hipóteses fáticas, ou seja, uma verdade construída pelo processo a partir de uma certeza eminentemente jurídica, com as limitações epistemológicas existentes em toda reconstrução histórica, aliadas aos regramentos e restrições legais dos meios de prova ${ }^{6}$.

Nesse sentido, vê-se que mesmo Michele Taruffo, defensor de uma visão mais extrema da possibilidade de obtenção da verdade dentro do processo, ainda assim admite limitações cognitivas em face de regras processuais, quando afirma que o tipo de verdade a ser estabelecida e aceita no processo é um problema que deve ser solucionado pelos limites legais e do valor que cada ordenamento impõe à busca da verdade ${ }^{7}$.

Todavia, mesmo conformando-se com essa feição, relativista e restrita, entendemos que a busca pela verdade não deixa de ser um dos objetivos e fundamentos do processo. Beltrán defende que "o sistema não pode prescindir da busca da verdade como objetivo institucional do processo (e, portanto, da aplicação do direito), visto que, de outro modo, o sistema entraria em colapso" ${ }^{\text {. }}$

Nossa legislação possui diversos elementos que fortalecem a conclusão de que a verdade é um fundamento do processo, especialmente o penal. Nosso Código determina que a primeira pergunta que seja feita ao réu no interrogatório seja relativa à veracidade das acusações feitas contra ele. A legislação penal, da mesma forma, criminaliza a

6 BADARÓ, Gustavo Henrique Righi Ivahy. O ônus da prova no processo penal. São Paulo: Editora RT, 2003, p. 31.

7 "Qué tipo de verdad es establecida en el proceso, en qué medida resulta aceptable y su proximidad o lejanía de la verdad que puede establecerse en otros contextos cognoscitivos, es un problema que sólo puede tener soluciones concretas y específicas en función de la naturaleza, de la amplitud y de la incidencia de los límites que imponen las normas de un determinado ordenamiento a la búsqueda de una versión verdadera de los hechos" (Taruffo, Michele. La prueba de los hechos. Madrid: Trotta, 2005, p. 79).

8 BELTRÁN, Jordi Ferrer. A prova é liberdade, mas não tanto: uma teoria da prova quase-benthamiana. In: DIDIER Jr., Fredie et al (coord.). Provas. Coleção Novo CPC. Doutrina Selecionada. $2^{\mathrm{a}}$ Ed. rev. e atual. Salvador: Juspodium, 2016, p. 113. 
calúnia, a denunciação caluniosa e o falso testemunho, que são condutas que, dentre outras coisas, atentam contra a verdade. Mesmo na legislação civilista, há o direito de resposta, com o intuito de esclarecimento da verdade, além do entendimento jurisprudencial de que a liberdade de expressão não garante o direito de mentir. Em qualquer ramo do direito, veremos menção à verdade como elemento ético mínimo das relações humanas e, portanto, jurídicas.

O direito enquanto produto e produtor da cultura deve sempre buscar harmonizar suas decisões com a realidade que está julgando, especialmente nas conclusões fáticas, já que uma completa discrepância da conclusão do Magistrado com o que efetivamente as partes vivenciaram prejudica a aceitabilidade da decisão, inibe a solução dos conflitos e mitiga o efeito geral de regulador de condutas do direito.

Doutrinadores como Khaled Jr. entendem que a verdade do processo é produzida analogicamente através de uma construção narrativa de rastros do passado, que de nenhuma forma poderia ser tida como uma correspondência do fato que se está investigando, sequer relativa ou aproximada. Afirma que o saber processual, por ser construído de rastros, "pertence a outro patamar cognitivo que o da correspondência”. Mesmo ele, contudo, não defende extirpá-la por completo das entranhas processuais, afirmando que - em sua teoria - ela "não será expulsa, mas redimensionada, perdendo seu lugar canônico"10.

Neste momento, começa a surgir a distinção entre o peso da verdade no processo civil e no processo penal. Como, na esfera privada, se está lidando, quase sempre, com direitos disponíveis e/ou de menor significância constitucional na esfera dos direitos fundamentais, a busca da verdade assume um papel inferior, podendo sucumbir diante de interesses constitucionais de igual ou maior relevância.

Vale dizer, embora se reconheça a busca da verdade como um dos fins do processo, ele não é o único, e outros interesses, como a duração razoável do processo, intimidade, honra, segredos de estado, sigilos

9 KHALED Jr., Salah H. A produção analógica da verdade no processo penal. Revista Brasileira de Direito Processual Penal. Porto Alegre, vol. 1, 2015, p. 175.

10 KHALED Jr., Salah H. A busca da verdade no Processo Penal: para além da ambição inquisitorial. São Paulo: Atlas, 2013, p. 335. 
profissionais e segurança jurídica, podem impor um sacrifício epistemológico ${ }^{11}$, inclusive por meio da criação de regras de limitações probatórias, de modo que o processo chegue ao seu fim com a consolidação de uma decisão sem sequer a presunção de se ter chegado à verdade, mesmo que formal.

O processo penal, por outro lado, lida com o direito à vida e à liberdade, e, dada suas superioridades axiológicas, a busca da verdade assume uma feição mais relevante àquela assumida no processo civil. Diz, Ferrajoli, que "se uma justiça penal integralmente com verdade constituiu uma utopia, uma justiça penal completamente sem verdade equivale a um sistema de arbitrariedade" ${ }^{12}$.

Reconhece-se, assim como o fez Eugênio Pacelli ${ }^{13}$ e Salah H. Khaled Jr, que o dogma da busca da verdade real, aliada à crença de que ela estaria efetivamente ao alcance do Estado, acabou por fortalecer uma cultura inquisitiva legitimadora de abusos e desvios de autoridades públicas, ampla e irrestrita iniciativa probatória do juiz e relativização de direitos fundamentais, o que não se está advogando de nenhuma forma.

Khaled Jr. vai além quando afirma que mesmo a visão relativista da verdade correspondente que ora se defende é um refúgio argumentativo para legitimar uma ambição inquisitorial ${ }^{14}$. Ele, inclusive, rejeita a verdade como valor finalístico do processo, ainda que sob o prisma relativista, afirmando que defender que a verdade não pode ser perseguida a qualquer custo ainda é dizer que ela deve ser perseguida, e esse discurso ainda se mostra retoricamente apto a legitimar atuação judicial abusiva e inquisitorial ${ }^{15}$. Ao seu ver, a ênfase deve ser nas regras do jogo processual e nunca na busca pela verdade.

Contudo, com a devida vênia, concordamos com Ferrajoli quando ele salvaguarda o valor teórico e político da ideia de busca da verdade, redefinindo-o como "um modelo limite, nunca plenamente

11 BELTRÁN, Jordi Ferrer. Op. Cit., p. 110.

12 FERRAJOLI, Luigi. Op. Cit., p. 48.

13 OLIVEIRA, Eugênio Pacelli de. Curso de Processo Penal. $8^{\mathrm{a}}$ Ed. Rio de Janeiro: Lumen Juris, 2007, p. 281.

14 KHALED Jr., Salah H. Op. Cit. p. 11.

15 KHALED Jr., Salah H. Op. Cit. p. 131. 
alcançável, senão apenas aproximável e, sobretudo, se forem esclarecidas as condições na presença das quais este pode ser mais ou menos satisfeito" ${ }^{16}$, sem que isso signifique um retorno às práticas inquisitivas. Especialmente no processo penal, o que se defende é que um sistema jurídico não se sustenta eticamente se ele é capaz de impor uma pena privativa de liberdade a uma pessoa por meio de um processo que não considere a verdade sequer como um objetivo relevante.

Nesse sentido, nossas conclusões convergem com a de Badaró quando ele afirma que a busca da verdade é um critério legitimador da atividade jurisdicional, não se podendo considerar justa uma sentença que não seja oriunda de um processo que aspirou uma correta verificação dos fatos ${ }^{17}$. Também Taruffo afirma que "independentemente do critério jurídico que se utilize para definir e valorar a justiça de uma decisão, pode-se defender que esta nunca é justa se está fundada em uma determinação errônea ou inaceitável dos fatos"18.

Inolvidável que o processo penal é regido pelos princípios da presunção de inocência e in dubio pro reo, importantes conquistas civilizatórias que impõem o ônus probatório à acusação e determinam que a condenação somente pode advir de um estado de certeza do julgador, nunca de dúvida. Este estado de certeza é incidente principalmente sobre as hipóteses fáticas submetidas à apreciação do julgador, e se configurará em uma convicção de que determinados enunciados que compõem o fato típico criminoso (João disparou uma arma em face de Carlos; João quis atingir Carlos com o disparo; Carlos veio a óbito em decorrência das lesões causadas pelo disparo, dentre outros) são verdadeiros, no sentido de plausibilidade ante as informações que se tem deles.

Para Ferrajoli, no processo penal, "o nexo exigido pelo princípio de estrita legalidade entre a 'validez' da decisão e a 'verdade' da motivação é mais forte do que qualquer outro tipo de atividade judicial”"19,

16 FERRAJOLI, Luigi. Op. Cit., p. 49.

17 BADARÓ, Gustavo Henrique Righi Ivahy. O ônus da prova no processo penal. São Paulo: Editora RT, 2003, p. 26.

18 TARUFFO, Michele. Op. Cit., p. 64 (tradução livre).

19 FERRAJOLI, Luigi. Op. Cit, p. 50. 
conclusão essa advinda, justamente, da natureza das sanções impostas e das funções preventivas geral e especial do direito penal.

A sociedade não se desestimulará da prática de determinada conduta criminosa se não restar convencida de que a pessoa certa foi punida, e tal convicção será idealmente alcançada com uma fundamentação que estiver amparada na convicção do Magistrado de ter caminhado em direção à verdade dos fatos, seja ela entendida como a reconstrução histórica aproximada dos relativistas ou a verdade analógica construída por rastros, defendida por Khaled Jr, para quem "o juiz não pode condenar sem narrativamente fazer jus à exigência de verdade na sentença" ${ }^{20}$. Da mesma forma, não se pode conceber que o Estado possa impor o sofrimento da restrição da liberdade de um indivíduo se não baseada em uma fundamentação amparada numa conclusão de certeza da dinâmica fática do evento criminoso.

Decerto que não se pode elevar a busca da verdade a um patamar que lhe permita a inobservância apriorística das garantias processuais. A prova ilícita continuará ilícita, mesmo que possa contribuir com a melhor tomada consciente da decisão. A tortura continuará sendo um crime e seu produto inadmissível, mesmo que se obtenham informações relevantes ao deslinde da causa.

Dentro da já exposta visão de Ferrajoli, admite-se a busca da verdade como relevante valor processual se restarem estabelecidas as condições na presença das quais ela pode ser mais ou menos satisfeita, e estas condições são as garantias processuais, a observância das regras procedimentais e o respeito aos direitos fundamentais. Como dito, o direito trabalha apenas com uma verdade formal advinda de um estado de certeza jurídica, construída a partir das limitações impostas previamente pela legislação processual.

Afirma-se, contudo, que a busca da verdade, sendo um fundamento ético do processo penal, deve ser utilizada como elemento jurídico de confrontação com outros princípios para solução proporcional de controvérsias, quando o ordenamento assim o permitir, mas, principalmente, como parâmetro hermenêutico na interpretação do conjunto probatório colacionado aos autos.

20 KHALED Jr., Salah H. Op. Cit., 2015, p. 177. 


\section{A INSUFICIÊNCIA DA CONFISSÃO PARA FORMAÇÃO DA CERTEZA CONDENATÓRIA: A BUSCA POR UMA CONVICÇÃO CONTEXTUALIZADA}

No livro "O caso Thomas Quick - A invenção de um assassino em série" ${ }^{21}$, o jornalista Hannes Rastam conta a história real do sueco Sture Bergwall (auto renomeado Thomas Quick) que, nos anos 90, confessou a prática de mais de 30 homicídios na região da Escandinávia, sendo chamado pela mídia de o maior serial killer da história da Suécia. Em face destas confissões, e nada mais, já que provas outras não havia, ele foi condenado por pelo menos oito dessas mortes.

Após vários anos presos, ao conceder entrevista ao autor do livro para a gravação de um documentário, ele finalmente admitiu que nunca cometeu nenhum dos crimes os quais confessou, e que o fez apenas por gostar da atenção que recebia em face da repentina fama midiática (mitomaníaco). A partir de um longo e minucioso trabalho investigativo e processual, narrado no mencionado livro, conseguiu-se então reverter suas condenações ante a prova da impossibilidade de Sture Bergwall ter cometido os crimes pelos quais foi condenado.

Embora pertencente a outra realidade cultural e jurídica, este caso simboliza algo que é comum a diversos ordenamentos jurídicos, os quais costumam orientar suas investigações e suas legislações para forçar uma confissão e, assim, dispensar o Estado de seu ônus de provar judicialmente a acusação.

A confissão no processo penal sempre foi vista como a maior das provas, aquela com a qual não haveria necessidade de qualquer outro procedimento investigativo e a partir da qual poderia haver a condenação imediata, o que veio a ser reforçado pelas legislações que consolidaram o instituto da colaboração premiada, como abordado mais adiante.

Na legislação processual penal de vários países ainda vigora uma hipervalorização judicial da confissão. Em Portugal, há casos em que a confissão plena não configura em si uma prova, mas um ato de renúncia à produção de provas e consequente aceitação dos fatos apura-

21 RASTAM, Hannes. O caso Thomas Quick: A invenção de um assassino em série. Rio de Janeiro: Record, 2014. 
dos como provados ${ }^{22}$, próximo ao que acontece na Inglaterra, onde, se o réu se declarar culpado, desincumbe-se a acusação do ônus da prova, passando-se direto à sentença, privilegiando-se a celeridade em detrimento do alcance da verdade ${ }^{23}$.

Situação similar se verifica nos Estados Unidos, em que, inclusive, cerca de noventa por cento dos casos criminais se resolve com plea bargains ${ }^{24}$, situações em que o réu aceita acordo com o órgão acusador e confessa sua culpa (guilty plea) para receber uma pena menor, sendo tal acordo homologado judicialmente com dispensa da realização de julgamento.

A Espanha possui um sistema intermediário, em que a confissão poderá ser tida como suficiente para a condenação apenas nos casos em

22 O art. 344 do Código de Processo Penal Português estabelece: "1 - No caso de o arguido declarar que pretende confessar os factos que lhe são imputados, o presidente, sob pena de nulidade, pergunta-lhe se o faz de livre vontade e fora de qualquer coacção, bem como se se propõe fazer uma confissão integral e sem reservas. 2 - A confissão integral e sem reservas implica: a) Renúncia à produção da prova relativa aos factos imputados e consequente consideração destes como provados; b) Passagem de imediato às alegações orais e, se o arguido não dever ser absolvido por outros motivos, à determinação da sanção aplicável; e c) Redução da taxa de justiça em metade. 3 - Exceptuam-se do disposto no número anterior os casos em que: a) Houver co-arguidos e não se verificar a confissão integral, sem reservas e coerente de todos eles; b) O tribunal, em sua convicção, suspeitar do carácter livre da confissão, nomeadamente por dúvidas sobre a imputabilidade plena do arguido ou da veracidade dos factos confessados; ou c) O crime for punível com pena de prisão superior a 5 anos. 4 - Verificando-se a confissão integral e sem reservas nos casos do número anterior ou a confissão parcial ou com reservas, o tribunal decide, em sua livre convicção, se deve ter lugar e em que medida, quanto aos factos confessados, a produção da prova”. PORTUGAL. Código de Processo Penal. Disponível em: http://www.pgdlisboa.pt/leis/ lei_mostra_articulado.php?ficha $=301 \&$ artigo_id $=\&$ nid $=199 \&$ pagina $=4 \&$ ta bela $=$ leis\&nversao $=\&$ so_miolo $=$. Acesso em 26.12.2016.

23 VILARES, Fernanda Regina. A prova penal no direito inglês. In: FERNANDES, Antônio Scarance; ALMEIDA, José Raul Gavião de; MORAES, Maurício Zanoide de (coords.). Provas no processo penal: estudo comparado. São Paulo: Saraiva, 2011, p. 368.

${ }^{24}$ BUREAU OF JUSTICE ASSISTANCE. U.S. DEPARTMENT OF JUSTICE. Plea and Charge Bargaining. Research Sumary. Disponível em: https:// www.bja.gov/Publications/PleaBargainingResearchSummary.pdf. Acesso em 28 dez. 2016 
que o defensor, ao ser questionado, declare a desnecessidade de continuação do julgamento, hipótese em que o Tribunal determinará desde logo a sentença ${ }^{25}$, já abrindo um espaço para produção de outras provas caso seja interesse da defesa.

Nos países latinos, a legislação já fora muito mais reticente com a aceitação da confissão, até mesmo pelo histórico de regimes ditatoriais em que não eram escassos os relatos de maus tratos e torturas no ambiente policial, com confissões sendo extraídas a força por representantes do Estado. Entretanto, nas últimas modificações legislativas, tem-se visto uma abertura maior para espaços de negociabilidade penal.

A Argentina, por exemplo, traz no seu mais recente Código Procesal Penal de la Nación, possibilidades de procedimento abreviado para certos tipos de crime, quando o acusado manifeste expressa concordância com os fatos constantes da denúncia ${ }^{26}$, o que se acha em idêntica forma no recente Código Nacional de Procedimientos Penales do México ${ }^{27}$.

O que se observa, na verdade, é que, seja como elemento de prova seja como ato voluntário de renúncia à produção de provas, as legislações internacionais caminham em direção à glorificação da confissão, fazendo a opção político-legislativa de sacrificar a busca da verdade em prol da celeridade processual.

Cumpre destacar que não são só os casos de confissões coagidas e mitomaníacos que jogam dúvidas na legitimidade deste tipo de prova.

25 YOKAICHIYA, Cristina Emy. A utilização de novas tecnologias no processo penal espanhol: reflexões sobre tipicidade e atipicidade em matéria probatória. In: FERNANDES, Antônio Scarance; ALMEIDA, José Raul Gavião de; MORAES, Maurício Zanoide de (coords.). Provas no processo penal: estudo comparado. São Paulo: Saraiva, 2011, p. 332.

26 Código Procesal Penal de La Nación Argentina - artículo 288.- Presupuestos y oportunidad del acuerdo pleno. Se aplicará a los hechos respecto de los cuales el representante del Ministerio Público Fiscal estimare suficiente la imposición de una pena privativa de la libertad inferior a seis (6) años. Será necesario que el imputado acepte de forma expresa los hechos materia de la acusación y los antecedentes de la investigación preparatoria que la fundaren y manifieste su conformidad con la aplicación de este procedimiento.

Os artigos 201 em diante expressamente preveem procedimento simplificado quando o acusado "expresamente renuncie al juicio oral" e "Acepte ser sentenciado con base en los medios de convicción que exponga el Ministerio Público al formular la acusación”. 
Se levarmos em conta a gravidade das consequências da intervenção penal na esfera de direitos de um indivíduo, não é difícil vislumbrarmos a possibilidade de confissões protetivas, feitas para salvaguardar terceira pessoa em detrimento do confessado (e.g., mãe confessando crime do filho, ou irmão confessando de irmão ${ }^{28}$ ).

Ainda, no contexto da criminalidade organizada, em que há uma estrutura hierarquizada de cometimento de infrações, é recorrente que integrantes de baixo escalão assumam a responsabilidade por crimes praticados por seus superiores, seja pela promessa de recompensa seja pelo temor de sua vida.

Por fim, vê-se frequente o caso do acusado que acaba por confessar determinada circunstância do crime, apenas para ver encerrada prematuramente a investigação ou persecução penal e, assim, não serem descobertos outros elementos mais gravosos, como o cidadão que confessa um homicídio, alegando crime passional, para evitar que a investigação aprofunde e descortine que a morte se deu por uma dívida de drogas, de modo a enquadrar o homicida também como traficante de entorpecentes, ou, ainda, o empresário que confessa uma sonegação fiscal para evitar devassas em suas contas e identificação de outros crimes mais graves contra a administração.

Taruffo conclui que "se o enunciado alegado é falso, a não contestação (a confissão) não o torna verdadeiro [...] se o enunciado alegado é verdadeiro, a não contestação não o torna verdadeiro, porque ele já o é" ${ }^{29}$. Vale dizer, adotando-se a ideia de que aquilo que é o é independente da conclusão a que o processo alcançar, vê-se que a mera confissão não possui o condão de conferir veracidade ao enunciado de fato acusatório.

Entretanto, em sendo a verdade real inalcançável e podendo o processo fixar condições e pressupostos para a aceitabilidade de premissas fáticas de forma suficiente a justificar uma sentença condenató-

28 Caso dessa natureza pode ser visto na reportagem "Menor pode ter confessado crime para proteger irmão mais velho”. Disponível em: http://oglobo.globo.com/rio/menor-pode-ter-confessado-crime-para-proteger-irmao-maisvelho-4545619. Acesso em: 16 jan. 2017.

29 TARUFFO, Michele. Verdade Negociada? Revista Eletrônica de Direito Processual - REDP, vol. 13, n. 13, p. 634-657, 2014. p. 650. 
ria, poder-se-ia questionar se a confissão não poderia ser apenas uma dessas condições, apta a justificar o encerramento prematuro da atividade estatal com a prolação de sentença condenatória.

Não nos parece, contudo, que há espaço ou legitimidade para se fixar condição desta natureza, já que a convicção penal apta à desconstituição da presunção de inocência deve se formar a partir da análise contextualizada do arcabouço probatório e não pela conformação com um único elemento de prova, mesmo que confessional.

Pontes de Miranda, ao abordar o assunto das provas, em seu Tratado de Direito Privado, afirma que as regras jurídicas sobre ônus da prova devem pressupor a subjetividade de toda incerteza, no sentido de que a necessidade de se provar determinado enunciado de fato reside sempre na circunstância de que as pessoas que analisam o fato não possuem informações suficientes acerca dele para formar a mesma conclusão. Com isso em mente, apenas com a colação do maior número de provas possível, e análise conjunta de todas elas, poder-se-ia obviar a divergência entre as pessoas que apreciam o mesmo fato, e, assim, chegar-se uma coincidência intersubjetiva de enunciados ${ }^{30}$.

Dentro das ideias da presunção de inocência e in dubio pro reo, não se pode querer cogitar uma certeza jurídica condenatória a partir de um único elemento probatório que, historicamente, possui tantos vícios a ele relacionados. Vale dizer, há uma imposição constitucional de que o processo caminhe sempre com a conclusão contrária à condenação, apenas infirmando-se esta conclusão a partir de um estado de certeza acerca da hipótese acusatória. Nesse sentido, tem-se que quanto maior o conjunto probatório, quanto mais elementos de informação dispor o Magistrado para desenvolver sua atividade cognitiva, mais próximo estará do conhecimento verdadeiro e mais legítima será sua decisão ${ }^{31}$.

30 MIRANDA, Pontes de. Tratado de Direito Privado. $4^{\mathrm{a}}$ Ed. São Paulo: Revista dos Tribunais, 1983, p. 421-424.

31 Chegam a essa conclusão: NARDELLI, Marcella Alves Mascarenhas. A função epistêmica do processo e as limitações probatórias: o direito à não autoincriminação e sua (in)aplicabilidade no Processo Civil; CAMBI, Eduardo. Teoria das cargas probatórias dinâmicas (distribuição dinâmica do ônus da prova) - exegese do artigo 373, §§ $1^{\circ}$ e $2^{\circ}$ do NCPC; BELTRÁN, Jordi Ferrer. A prova é liberdade, mas não tanto: uma teoria da prova quase-benthamiana. Todos 
Inegavelmente a confissão penal é um importante elemento de prova, já que se traduz na concordância do réu acerca de determinado enunciado de fato da acusação, e, portanto, ilide o caráter litigioso da ação penal, dada a coincidência intersubjetiva de enunciados.

Inclusive, a confissão no processo civil - seja pelo reconhecimento da procedência do pedido seja pela composição - é causa de extinção imediata do feito, com resolução de mérito, de modo que a resolução amigável do litígio é suficiente para se conferir legitimidade à decisão judicial, independentemente de o Magistrado concluir ou aceitar que aquele fato (alegado pelo autor e aceito pelo réu) é verdadeiro, no sentido de plausível e conformado com as provas apresentadas.

Entretanto, em sendo a verdade um relevante valor finalístico do Processo Penal, o julgador não pode se contentar apenas com a confissão do acusado. Isso não só por ela não se mostrar suficiente à formação de uma certeza, como pelos riscos concretos de manipulação processual, devendo então se utilizar das técnicas de confirmação, confronto e controle, para averiguar sua coerência com os demais elementos de prova utilizados, e se chegar a uma verdade processual resultante da análise contextualizada das provas.

Estas técnicas judiciais, descritas por Dominioni, consistem em acostar outros elementos de prova que traduzam a mesma hipótese fática daquela sob análise (confirmação), analisar elementos estranhos à prova que, se demonstrados, conferem veracidade ao depoimento (confronto), e identificação de elementos intrínsecos e extrínsecos do declarante que possam conduzir a (in) idoneidade do depoimento (controle), tais como tempestividade da declaração, espontaneidade, aspectos morais, culturais e sociais da personalidade, capacidade profissional, dentre outros ${ }^{32}$.

A partir da análise de todo o arcabouço probatório produzido, o Juiz pode construir a dinâmica fática que utilizará como base para formação de seu convencimento acerca da hipótese acusatória, exte-

In: DIDIER Jr., Fredie et al (coord.). Provas. Coleção Novo CPC. Doutrina Selecionada. $2^{\mathrm{a}}$ Ed. rev. e atual. Salvador: Juspodium, 2016.

32 GOMES FILHO, Antônio Magalhães. A motivação das decisões penais. São Paulo: RT, 2001, p. 156. 
riorizando o processo intelectual realizado, conferindo racionalidade à sua fundamentação condenatória.

Ferrajoli $^{33}$ trata a decisão judicial acerca de determinado fato como um saber-poder, ou seja, como uma conjunção de conhecimento (veritas) e decisão (auctoritas), aduzindo que o Juiz possui o poder de coercitivamente impor a "verdade" acerca de determinado enunciado de fato. Neste contexto, saber e poder se mantem inversamente proporcionais: quanto mais conhecimento do fato (provas) o Juiz tem, menos ele exerce sua autoridade, e quanto menos provas ele possuir, mais arbitrária será sua decisão.

\section{A FUNDAMENTAÇÃo DA DECISÃo PENAL E OS EQUívocos DA SÚMULA N. 545, DO SUPERIOR TRIBUNAL DE JUSTIÇA}

Inobstante tenhamos concluído que a confissão não é um elemento apto a sozinho sustentar uma sentença penal condenatória, não ignoramos a sua incontestável importância como elemento de prova, já que usualmente uma confissão verdadeira e espontânea contribui consideravelmente para a formação do convencimento judicial, principalmente ao preencher determinadas lacunas na construção da dinâmica dos fatos criminosos.

Ainda, em uma esfera extra autos, a confissão é um importante instrumento de arrependimento, a permitir o desenvolvimento de um raciocínio retrospectivo acerca dos atos praticados e suas consequências, fazendo com que, idealmente, o acusado compreenda o dano social de sua conduta e a necessidade da reprimenda estatal, favorecendo o processo de aprisionamento e ulterior reinserção social.

Com isso em mente, o Código Penal prevê, em seu art. 65, inciso III, alínea d, que a confissão espontânea da autoria de um crime é uma circunstância que sempre ("sempre" sendo a palavra-chave) deverá atenuar a pena do réu, transformando-se em um instrumento de estímulo a determinada manifestação de vontade do réu a partir do estabelecimento de uma "recompensa" judicial.

33 Ferrajoli, Luigi. Op. Cit., p. 49. 
Após anos de discussão acerca da atenuante da confissão espontânea, seu grau de diminuição de pena, e, principalmente, causas de (in) aplicabilidade, o Superior Tribunal de Justiça editou o enunciado n. ${ }^{\circ} 545$ de sua súmula, com a seguinte redação: “quando a confissão for utilizada para a formação do convencimento do julgador, o réu fará jus à atenuante prevista no art. 65, III, d, do Código Penal".

Ao se definir o enunciado com esse teor, construiu-se a ideia de que poderiam haver casos em que o réu, mesmo confessando, não faria jus à atenuante prevista em lei. Seriam as situações em que o conjunto de provas é de tal sorte extenso ou convincente que o magistrado não necessitaria fazer referência à confissão para fundamentar seu julgado.

Notadamente, a jurisprudência passou a negar a aplicação da atenuante da confissão aos casos de prisão em flagrante ${ }^{34}$, tendo o Supremo Tribunal Federal -STF já decidido que "a prisão em flagrante é situação que afasta a possibilidade de confissão espontânea, uma vez que esta tem como objetivo maior a colaboração para a busca da verdade real" 35 .

Defende-se, portanto, que alcançando o Magistrado a "verdade real" sem a colaboração do acusado, sua eventual confissão seria irrelevante para o processo e, assim, não mereceria ele a atenuante legal.

Esta lógica possui dois problemas inafastáveis, um de ordem legal e outro cognitivo.

Em termos de subsunção, não há espaço, na exegese do Código Penal, para que o Magistrado deixe de aplicar a atenuante de pena nos casos em que o réu confesse a autoria do delito, já que a taxatividade e objetividade da expressão "sempre" não permite o auto-regramento de vontade do julgador a ponto de compreender a atenuante como um negócio jurídico. Pouco importa as razões que levaram o acusado a con-

34 BRASIL. TJAL - Tribunal de Justiça de Alagoas. Acórdão na Apelação Criminal n. ${ }^{o}$ 0023486-63.2012.8.02.0001. Câmara Criminal. Relator Desembargador José Carlos Malta Marques. Julgado em 22.07.2015. BRASIL. TJAL - Tribunal de Justiça de Alagoas. Acórdão na Apelação Criminal n. ${ }^{o}$ 0012783-54.2004.8.02.0001. Câmara Criminal. Relator Desembargador Sebastião Costa Filho. Julgado em 10.04.2013.

35 BRASIL. STF - Supremo Tribunal Federal. Acórdão no Habeas Corpus n. ${ }^{o}$ 108.148/MS. Primeira Turma. Relator Ministro Ricardo Lewandowski. Julgado em 07.06.2011. 
fessar, ou a quantidade de outras provas que se conseguiu produzir, se ele o fez terá sua pena atenuada.

Doutra banda, a Súmula do STJ parte do equivocado pressuposto de que um elemento de prova constante dos autos, e ao qual o julgador teve acesso, não participou da formação de seu convencimento. Vale dizer, ela presume a possibilidade de o juiz ter a capacidade sobre -humana de decidir o que penetrará a sua psique e o que permanecerá nos autos alheio à sua capacidade cognitiva.

Há, no processo de construção da decisão jurídica, o livre convencimento motivado, que permite que o magistrado analise e valore as provas da maneira que lhe convier, desde que fundamente sua decisão e exponha as razões de sua valoração. Nessa lógica, o livre convencimento motivado se apresenta como uma autorização para que o juiz, com a coercibilidade intrínseca da jurisdição, estabeleça se determinado enunciado de fato está provado ou não, e, assim, qual a "verdade" que será considerada para fins de estabelecimento das premissas da sentença penal.

Entretanto, como alerta Antônio Magalhães Gomes Filho, o livre convencimento não implica autorização para arbitrariedade, dada a necessidade de fundamentação. Para ele, a motivação da sentença penal condenatória deve levar em consideração todas as provas acostadas aos autos, nem que seja para rejeitar a premissa fática que ela originalmente pretendia provar, "não sendo racional utilizar-se apenas daquelas que confirmem uma conclusão pré-estabelecida, simplesmente desconsiderando outras que poderiam invalidar um resultado que se quer a todo custo alcançar" ${ }^{36}$.

Apenas com a exposição de todos os meios de prova, com a costura lógica daqueles que coadunam com a sua conclusão e o confronto e derrocada daqueles que outrora poderiam contrariá-la, pode haver controle do arbítrio judicial, facilitado pela exposição das premissas que permitiram formar seu convencimento. Nessa ótica, não se mostra legítima a decisão condenatória que não faça referência a uma das provas produzidas no curso da instrução, notadamente a confissão.

Entretanto, mesmo que não se entenda pela necessidade de menção a todos os elementos de prova constantes dos autos, e se defen-

36 GOMES FILHO, Antônio Magalhães. Op. Cit., p. 158. 
da, como o faz a maioria, que o magistrado está livre para, ao condenar o réu, não fazer referência à confissão, desde que obtenha êxito em expor sua convicção a partir de outros elementos de prova, ainda assim não se poderá dizer que a confissão não participou do processo de construção do seu conhecimento.

Sem a pretensão de um tratado acerca das teorias do conhecimento, é cediço que a aprendizagem que dá azo à convicção é o acúmulo consciente e inconsciente das informações às quais o aprendiz é exposto. A partir do momento em que o julgador tem contato com algum elemento de informação, ele necessariamente é contaminado por ele e aquela informação passa a integrar o espectro de referências que utilizará para balizar a incorporação de novos conhecimentos, de modo que não se pode conceber a ideia de um elemento de prova que, conhecido, não tenha participado da formação de seu convencimento.

Ademais, ao contrário do que o STJ e a jurisprudência parecem crer, não há como se analisar um elemento de prova de forma descontextualizada, como se ele sozinho pudesse levar à uma conclusão suficientemente plausível para se desconstituir uma presunção de inocência. Os elementos de prova colhidos durante um flagrante, por exemplo, só se tornaram suficientes para fundamentar a condenação porque houve a confissão. Caso o réu tivesse negado a prática criminosa e/ou agregado elementos defensivos à sua conduta, a investigação e o processo necessitariam caminhar para uma maior instrução probatória ou o magistrado deveria aditar sua fundamentação para enfrentar a contradição.

Diz Beltrán que "o resultado da valoração da prova é sempre contextual, isto é, referido a um determinado conjunto de elementos de juízo[...]. Se o conjunto mudar, por acréscimo ou subtração de algum elemento, o resultado pode perfeitamente ser outro" ${ }^{37}$. Embora haja resistência judicial, é cediço que nosso Código de Processo Penal não se conforma apenas com a confissão e, embora reconheça seu valor, impõe a formação de uma base probatória maior com a qual ela possa ser confrontada, de modo a reduzir o arbítrio do Estado e permitir a aproximação máxima possível com a certeza exigida pelos princípios regentes do sistema jurídico-penal.

37 BELTRÁN, Jordi Ferrer. Op. Cit., p. 108. 


\section{A COLABORAÇÃo PREMIADA E NEGOCIABILIDADE DA VERDADE NO PROCESSO PENAL}

A relevância de se rediscutir questões como a busca da verdade no processo penal e a insuficiência da confissão para, sozinha, sustentar a fundamentação de uma sentença condenatória surge do movimento moderno do sistema jurídico penal que novamente glorificou a força probatória da confissão e institucionalizou a negociabilidade da verdade no processo penal, através das provas produzidas nas colaborações (ou delações) premiadas.

Tal instituto está previsto especialmente na Lei de Organizações Criminosas (Lei n. 12.850/2013), que o trata como um meio de obtenção de prova, através do qual um dos integrantes da organização resolve confessar sua participação em certos crimes e colaborar com o sistema de justiça criminal, fornecendo informações relevantes.

Inobstante se reconheça a eficácia deste instrumento de produção de prova na investigação criminal de organizações criminosas, assim como se reconheceu a importância da confissão em si, deve-se analisar tal contexto com cautela, buscando sempre moldar a colaboração premiada para adequar a prática de sua colheita e utilização em contornos constitucionalmente definidos.

Afora diversas outras críticas que já foram feitas pela doutrina à colaboração premiada, não adequadas ao propósito deste artigo, vêse que uma é de especial relevância, o sacrifício cognitivo que algumas formas dela impõem ao processo.

A Lei de Organizações Criminosas instituiu, entre os artigos $4^{\circ}$ e $7^{\circ}$, uma modalidade de negócio jurídico processual, em que há um leque legal de benesses que o Ministério Público pode negociar com o colaborador a depender do grau de relevância de sua delação. A Lei prevê benefícios que variam entre uma imunidade de denúncia, o perdão judicial, redução de pena, substituição por penas alternativas ou progressão antecipada de regime.

Surge, portanto, um plea bargain à brasileira, em que a acusação e a defesa podem fazer um acordo - com base apenas na confissão do acusado e eventuais elementos de informação pré-processuais - o qual, após homologado pelo Juiz, servirá de prova para instruir processo con- 
tra os outros integrantes da organização criminosa e fixará prematuramente as sanções impostas ao delator.

Criou-se uma hipótese em que a verdade de fatos típicos é objeto de negócio jurídico extraprocessual, na medida em que as partes acordam a aceitabilidade jurídica de determinada premissa relacionada ao crime sem que seja produzida judicialmente nenhuma prova, nos casos em que a colaboração ocorre ainda na fase inquisitorial.

A negociabilidade da verdade sempre foi uma questão controversa. No processo civil, filiamo-nos à ideia de que "a autonomia da vontade pode estipular quais os critérios aptos a estabelecer a fixação dos fatos no processo" ${ }^{38}$, de modo que os fatos a serem levados em conta para a decisão podem ser livremente convencionados pelas partes, desde que voluntaria e conscientemente.

No processo penal, todavia, dada a já elaborada função ética da busca da verdade e a natureza dos interesses envolvidos, não há espaço para autonomia da vontade do órgão acusador estatal quanto à negociabilidade das premissas fáticas.

O arbítrio judicial é um problema generalizado, sem exclusividade a nenhum ramo do direito. Entretanto, no campo penal, ele possui consequências danosas e irreversíveis à vida, à liberdade, à integridade física e psíquica do indivíduo, de modo que toda e qualquer mudança legislativa, política ou pesquisa que envolva a esfera das decisões judiciais penais deve sempre ser orientada para se controlar e reduzir o arbítrio, nunca para incrementá-lo.

Retomando o pensamento de Ferrajoli, quanto menos veritas, mais auctoritas. Quão menor for o conjunto de informações à disposição do magistrado, maior será o arbítrio na fixação da verdade processual. Estas informações, diga-se de passagem, devem ser majoritariamente produzidas sob o crivo do contraditório e da ampla defesa no curso de um processo judicial, com respeito a todas as garantias conferidas pela Constituição, já que estes foram os limites estabelecidos para se aceitar o modelo de busca da verdade dentro do nosso processo.

38 SILVA, Beclaute Oliveira. Verdade como objeto do negócio jurídico processual. In: DIDIER Jr., Fredie et al (coord.). Provas. Coleção Novo CPC. Doutrina Selecionada. $2^{\text {a }}$ Ed. rev. e atual. Salvador: Juspodium, 2016, p. 302. 
O controle da arbitrariedade judicial penal advém de a fundamentação da sentença analisar todo um conjunto probatório produzido, confrontando-o e contextualizando-o, independentemente de ter havido confissão ou não, sendo ela apenas mais um importante elemento na formação da convicção do juiz.

Afora as problemáticas éticas advindas da situação de pressão e controle que se impõe ao investigado como forma de coagi-lo indiretamente à delação, vê-se que foi construída uma autorização legal para que o acusador público e o magistrado homologador formem seu convencimento pleno com base apenas na palavra do delator e de elementos ou inquirições pré-processuais ${ }^{39}$, configurando um incontestável retrocesso na esfera dos direitos fundamentais penais.

Decerto que há previsão legal de que nenhuma sentença condenatória será proferida com base apenas nas declarações do delator, mas a fixação apriorística de sua pena sem a realização de uma instrução probatória judicial, mesmo que eventualmente reduzida, é medida que tramita contra toda a corrente de evolução do pensamento processual penal.

Como exemplo, podemos citar o caso em que o colaborador de uma organização criminosa, com os elementos de informação produzidos na investigação, firma acordo de colaboração premiada em que aceita uma penalidade adequada para uma imputação de tráfico de entorpecentes, apenas para, ao final da instrução processual conduzida pelo magistrado, verificar-se que sua conduta melhor seria tipificada como associação para o tráfico, que possui uma pena menor.

Seguindo a lógica da negociabilidade da verdade no processo penal, oriunda da compreensão judicial da supremacia da confissão, o magistrado não teria quaisquer motivos para rever os termos da delação homologada, já que fruto da autonomia de vontade das partes envolvidas. Entretanto, o reconhecimento da verdade como fundamento ético do processo penal impõe que a decisão final se mantenha, ao menos quanto às premissas fáticas, vinculada à convicção advinda da

39 VASCONCELLOS, Vinicius Gomes. Barganha e justiça criminal negocial: análise das tendências de expansão dos espaços de consenso no processo penal brasileiro. São Paulo: IBCCRIM, 2015, p. 176. 
análise contextualizada das provas e não presa à verdade negociada em acordo de colaboração.

Tão mais grave é a situação quando se observa que o acordo pode ser homologado sem que sequer o magistrado tenha qualquer contato com o colaborador, já que a lei apenas determina que ele poderá fazê-lo, criando a opção de fixação de uma pena privativa de liberdade sem que sequer o acusado tenha contato com o juiz sentenciante.

O processo penal da criminalidade organizada, para o colaborador, assume a feição de mero instrumento de convalidação de uma confissão extrajudicial confirmada por elementos de informação produzidos inquisitorialmente, quando nossa legislação e nossa cultura jurídica caminham para a rejeição da confissão como elemento de convicção plena do julgador penal e pela necessidade de confirmação das provas em sede de instrução processual acusatória.

Decerto que a legislação pode criar standards para a valoração de certas provas ou para a formação da certeza jurídica penal. Entretanto, não nos parece legítimo que se fulmine a presunção de inocência a partir da reglorificação da confissão e a confiança plena em elementos de informação inquisitivos, permitindo a negociabilidade da verdade entre órgão acusador e o réu. A ampla defesa e o contraditório, garantias constitucionais oriundas de importantes conquistas civilizatórias, se tornam meros adereços dispensáveis por economia psíquica do julgador ${ }^{40}$ que vê seu trabalho encerrado - quanto ao delator - em face do reconhecimento do poder inquestionável da confissão.

Nas provas produzidas contra os delatados a situação é mitigada, mas não deixa de carecer de atenção. Decerto que eles possuem o "privilégio" da instrução probatória, com ampla defesa e contraditório para apresentação de outros elementos de convencimento que possam se contrapor à dinâmica fática construída pelo delator. Entretanto, a manutenção da cultura jurídica de hipervalorização da confissão pode transformar essa instrução probatória do delatado em mera ratificação do convencimento do julgador, já formado pela versão do delator.

Assim, o sacrifício epistemológico que se atribui a certas modalidades de colaboração premiada não se verifica exclusivamente na im-

40 VASCONCELLOS, Vinicius Gomes, op. cit., p. 177. 
posição apriorística de penas ao delator com base em fatos estabelecidos pela confissão e elementos de informação pré-processuais. Verifica-se o sacrifício epistemológico, principalmente, na tendência jurisprudencial de hipervalorizar o depoimento do delator como indicativo definitivo de verdade quanto aos fatos em apuração, seja em seu próprio processo seja no dos delatados, resgatando a equivocada ideia de supremacia probatória da confissão.

\section{ConClusão}

Não se nega o valor probatório da confissão do acusado no processo criminal. Seja como um instrumento de colaboração com a justiça, manifestação de um arrependimento ou simplesmente estratégia defensiva para redução de pena, é fato que o sistema jurídico penal possui muito a ganhar com a postura do acusado em relatar voluntariamente a dinâmica dos fatos criminosos.

Entretanto, a prática do sistema jurídico penal demonstra a possibilidade real de contaminação desta prova, por problemas psíquicos do confessado, coação física e moral, confissões protetivas, pagas, ou, ainda, confissões instrumentalizadas para manipulação da justiça. Ademais, aliado a essas questões concretas e verificáveis individualmente, vê-se que há um empecilho ideológico para a supremacia confessional.

A busca da verdade, como fundamento ético do processo penal, impõe sempre a construção de um arcabouço probatório maior com o qual a confissão possa ser confrontada, segundo conclusão lógica advinda dos princípios constitucionais penais e que foi consolidada nas regras processuais dos artigos 197 e 200 do Código de Processo Penal.

Entretanto, a despeito da opção político-legal pela insuficiência da confissão, vê-se que a legislação específica contra o crime organizado buscou retomar a lógica de sua supremacia, possibilitando acordos de colaboração premiada que impõem, por homologação judicial, penas alternativas, perdões judiciais, imunidades de denúncia e reduções de pena àqueles que, confessando, contribuam para a incriminação dos demais partícipes do grupo criminoso. 
Permitir a imposição de qualquer sanção a partir unicamente da confissão do acusado, ou amparando-a em provas indiciárias eventualmente produzidas pelo próprio acusado, é o reconhecimento da inaptidão do Estado em conduzir um Processo Penal nos moldes definidos pelas regras constitucionais e legais.

Decerto que o combate ao crime organizado pode justificar a criação de novos standards para a conformação probatória penal. Entretanto, não se pode, com esse fundamento, aceitar um completo sacrifício epistemológico a partir de uma negociabilidade das premissas fáticas que fundamentem a sentença condenatória.

A formação da convicção penal legitimamente apta a desconstituir a presunção de inocência deve surgir da análise contextualizada dos elementos probatórios coligidos aos autos por meio do devido processo legal, e nunca da conformação duvidosa do réu a partir de elementos informativos colhidos inquisitivamente.

No âmbito das colaborações premiadas, o equívoco que se deve evitar, como já dito, é a hipervalorização do depoimento do delator seja em relação a ele seja quanto aos delatados - como indicativo definitivo da verdade dos fatos, formando o julgador sua convicção apriorística e transformando o processo em mero ratificador.

Para tanto, a fundamentação da decisão penal assume especial relevância, de modo que o julgador deve sempre expor sua convicção de forma contextualizada a partir da análise de todos os elementos de prova colhidos nos autos, sejam aqueles que corroboram a dinâmica fática contida na confissão, ou delação, sejam aqueles que porventura se contraponham a ela, de modo a mitigar o sacrifício epistemológico advindo da negociabilidade típica da confissão.

\section{REFERÊNCIAS}

BADARÓ, Gustavo Henrique. O ônus da prova no processo penal. São Paulo: RT, 2003.

BADARÓ, Gustavo Henrique. Processo Penal. $3^{\text {a }}$ Ed., rev., atual. e ampl.. São Paulo: RT, 2015. 
BELTRÁN, Jordi Ferrer. A prova é liberdade, mas não tanto: uma teoria da prova quase-benthamiana. In: DIDIER Jr., Fredie et al (coord.). Provas. Coleção Novo CPC. Doutrina Selecionada. $2^{\text {a }}$ Ed. rev. e atual. Salvador: Juspodium, 2016, p. 103-122.

BUREAU OF JUSTICE ASSISTANCE. U.S. DEPARTMENT OF JUSTICE. Plea and Charge Bargaining. Research Sumary. Disponível em: https://www.bja.gov/ Publications/PleaBargainingResearchSummary.pdf. Acesso em 28 dez. 2016.

CAMBI, Eduardo. Teoria das cargas probatórias dinâmicas (distribuição dinâmica do ônus da prova) - exegese do artigo $373, \S \S 1^{\circ}$ e $2^{\circ}$ do NCPC. In: DIDIER Jr., Fredie et al (coord.). Provas. Coleção Novo CPC. Doutrina Selecionada. $2^{\text {a }}$ Ed. rev. e atual. Salvador: Juspodium, 2016, p. 533-556.

FERRAJOLI, Luigi. Direito e razão: teoria do garantismo penal. $3^{\mathrm{a}}$ Ed. rev. São Paulo: Editora Revista dos Tribunais, 2010.

GOMES FILHO, Antônio Magalhães. A motivação das decisões penais. São Paulo: RT, 2001.

KHALED Jr., Salah H. A busca da verdade no Processo Penal: para além da ambição inquisitorial. São Paulo: Atlas, 2013.

KHALED Jr., Salah H. A produção analógica da verdade no processo penal. Revista Brasileira de Direito Processual Penal. Porto Alegre, vol. 1, p. 166-184, 2015. https://doi.org/10.22197/rbdpp.v1i1.9

IOKOI, Pedro Ivo Gricoli. A disciplina da prova no Código de Processo Penal mexicano. In: FERNANDES, Antônio Scarance; ALMEIDA, José Raul Gavião de; MORAES, Maurício Zanoide de (coords.). Provas no processo penal: estudo comparado. São Paulo: Saraiva, 2011, p. 179-221.

LAÊRTIOS, Diôgenes. Vidas e doutrinas dos filósofos ilustres. Tradução do grego, introdução e notas: Mário da Gama. $2^{\text {a }}$ Ed. Brasília: Editora da Universidade de Brasília, 2008.

MIRANDA, Pontes de. Tratado de Direito Privado. $4^{\text {a }}$ Ed. São Paulo: Revista dos Tribunais, 1983.

NARDELLI, Marcella Alves Mascarenhas. A função epistêmica do processo e as limitações probatórias: o direito à não autoincriminação e sua (in) aplicabilidade no Processo Civil. In: DIDIER Jr., Fredie et al (coord.). Provas. Coleção Novo CPC. Doutrina Selecionada. $2^{\text {a }}$ Ed. rev. e atual. Salvador: Juspodium, 2016, p. 55-81. 
OLIVEIRA, Eugênio Pacelli de. Curso de Processo Penal. $8^{\text {a }}$ Ed. Rio de Janeiro: Lumen Juris, 2007.

PORTUGAL. Código de Processo Penal. Disponível em: http://www. pgdlisboa.pt/leis/lei_mostra_articulado.php?ficha $=301 \&$ artigo_ $\mathrm{id}=\&$ nid $=199 \&$ pagina $=4 \&$ tabela $=$ leis $\&$ nversao $=\&$ so_miolo $=$. Acesso em $26 \mathrm{dez}$. 2016.

RASTAM, Hannes. O caso Thomas Quick: A invenção de um assassino em série. Rio de Janeiro: Record, 2014.

SILVA, Beclaute Oliveira. Verdade como objeto do negócio jurídico processual. In: DIDIER Jr., Fredie et al (coord.). Provas. Coleção Novo CPC. Doutrina Selecionada. $2^{\text {a }}$ Ed. rev. e atual. Salvador: Juspodium, 2016, p. 283-306.

TARUFFO, Michele. La prueba de los hechos. Madrid: Trotta, 2005.

TARUFFO, Michele. Verdade Negociada? Revista Eletrônica de Direito Processual - REDP, vol. 13, n. 13, p. 634-657, 2014.

VASCONCELLOS, Vinicius Gomes. Barganha e justiça criminal negocial: análise das tendências de expansão dos espaços de consenso no processo penal brasileiro. São Paulo: IBCCRIM, 2015.

VILARES, Fernanda Regina. A prova penal no direito inglês. In: FERNANDES, Antônio Scarance; ALMEIDA, José Raul Gavião de; MORAES, Maurício Zanoide de (coords.). Provas no processo penal: estudo comparado. São Paulo: Saraiva, 2011, p. 358-394.

YOKAICHIYA, Cristina Emy. A utilização de novas tecnologias no processo penal espanhol: reflexões sobre tipicidade e atipicidade em matéria probatória. In: FERNANDES, Antônio Scarance; ALMEIDA, José Raul Gavião de; MORAES, Maurício Zanoide de (coords.). Provas no processo penal: estudo comparado. São Paulo: Saraiva, 2011, p. 314-354. 


\section{DADOS DO PROCESSO EDITORIAL}

(http://www.ibraspp.com.br/revista/index.php/RBDPP/about/editorialPolicies)

- Recebido em: 07/11/2016 Equipe editorial envolvida

- Controle preliminar e verificação de plágio: $12 / 11 / 2016$

- Avaliação 1: 21/11/2016

- Avaliação 2: 23/11/2016

- Editor-chefe: 1 (VGV)

- Editora-associada: 1 (SRM)

- Revisores: 3

- Avaliação 3: 26/11/2016

- Decisão editorial preliminar: $14 / 12 / 2016$

- Retorno rodada de correções 1: 16/01/2017

- Decisão editorial 2: 16/01/2017

- Retorno rodada de correções 2: 20/01/2017

- Decisão editorial final: 23/01/2017

\section{COMO CITAR ESTE ARTIGO:}

RODRIGUES, Paulo Gustavo. A convicção contextualizada e a verdade negociada no processo penal: desmistificando a confissão como elemento de convencimento pleno do julgador penal. Revista Brasileira de Direito Processual Penal, Porto Alegre, vol. 3, n. 1, p. 103-130, jan./abr. 2017. https://doi.org/10.22197/rbdpp.v3i1.32

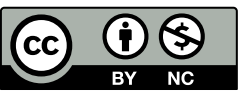

Esta obra está licenciada com uma Licença Creative Commons Atribuição-NãoComercial 4.0 Internacional. 